\title{
O prawnych aspektach dyscypliny w silach zbrojnych Rzeczypospolitej
}

\section{Na marginesie najnowszych prac Karola Lopateckiego ${ }^{1}$}

\begin{abstract}
Discipline is the soul of an army. It makes small numbers formidable; procures success to the weak, and esteem to all.
\end{abstract}

George Washington do kapitanów pułków wirginijskich, 29 lipca 1759 r. $^{2}$

Opinia wyrażona przez przyszłego triumfatora w wojnie o niepodległość kolonii amerykańskich mogłaby zostać wypowiedziana przez niemal każdego wojskowego w każdej epoce na każdej szerokości geograficznej. Niemniej jednak istotne jest, że Washington napisał to zdanie pod wpływem świeżych doświadczeń dowodzenia 1. pułkiem z Wirginii i prób przeobrażenia tej milicyjnej jednostki w oddział dorównujący wyszkoleniem i karnością regularnej armii brytyjskiej ${ }^{3}$. Nie jest też przypadkiem, że tworzone na przełomie XVIII i XIX stulecia armie narodowe, mimo iż opierały się na przymusowej służbie wojskowej mieszkańców państwa, czerpały wzorce organizacyjnodyscyplinarne nie ze swoich odległych średniowiecznych odpowiedników - formacji również rekrutowanych na podstawie obowiązku służby określonych grup ludności (m.in. pospolite ruszenie, obrona krajowa ${ }^{4}$ ), ale właśnie

${ }^{1}$ K. Łopatecki ,Disciplina militaris” w wojskach Rzeczypospolitej do polowy XVII wieku, Instytut Badań nad Dziedzictwem Kulturowym Europy, Białystok 2012, ss. 801; idem, Organizacja, prawo $i$ dyscyplina $w$ polskim i litewskim pospolitym ruszeniu (do polowy XVII wieku), Instytut Badań nad Dziedzictwem Kulturowym Europy, Białystok 2013, ss. 660.

${ }^{2}$ Cyt. za: The Book of Military Quotations, ed. P.G. Tsouras, St. Paul 2005, s. 127.

${ }^{3}$ Zob.: J. Titus, The Old Dominion at War: Society, Politics, and Warfare in Late Colonial Virginia, Columbia 1991, s. 41-45, 91-94; F. Anderson, Crucible of War: The Seven Years' War and the Fate of Empire in British North America, 1754-1766, New York 2000, s. 203.

${ }^{4}$ Najnowsza praca o służbie w pospolitym ruszeniu średniowiecznej Polski: K. Ginter, Udzial szlachty polskiej w pospolitym ruszeniu w XIV I XV wieku: Aspekty prawne i stan faktyczny, Kra- 
z profesjonalnych wojsk zaciężnych ${ }^{5}$. Świadczy to o głębokich przeobrażeniach, które zaszły w europejskich siłach zbrojnych w okresie wczesnonowożytnym.

Zmiany te określane są mianem rewolucji militarnej ${ }^{6}$, a ich znaczenie nie rozciągało się tylko na sprawy ściśle związane z wojskowością, ale obejmowało także kwestie polityczne, ustrojowe, gospodarcze i społeczne. Zagadnienia związane z dyscypliną wojskową winny się zaś znajdować w centrum wszelkich rozważań na temat szerszych konsekwencji przemian o charakterze militarnym, jak wskazuje na to chociażby przywoływany cytat. Dlatego też wskazuje się na bliski związek paradygmatu rewolucji militarnej z innym wielkim paradygmatem badań nad Europą XVI-XVIII wieku - paradygmatem dyscyplinowania spolecznego (Sozialdisziplinierung) ${ }^{7}$. Dyscyplina wojskowa jest postrzegana jako swego rodzaju ogólny model relacji społecznych, będących produktem wczesnonowożytnej modernizacji ${ }^{8}$.

Wszystko wskazuje, że mamy do czynienia z problemami wielkiej wagi. Dlatego badanie dyscypliny wojskowej w siłach zbrojnych Rzeczypospolitej może być bardzo istotnym przyczynkiem w debacie nad miejscem polsko-litewskiego państwa w kluczowych procesach modernizacyjnych epoki - jego europejskiej typowości lub nietypowości. Temat ten, pomimo swojego doniosłego znaczenia, cieszył się do tej pory umiarkowanym (w porównaniu z innymi kwestiami) zainteresowaniem historyków wojskowości Korony i Wielkiego Księstwa Litewskiego ${ }^{9}$. Należy również nadmienić, że część przedwojennej literatury przedmiotu nie spełnia współczesnych kryteriów naukowych. $Z$ tym większym zadowoleniem trzeba powitać pojawienie się dwóch wyjątkowo obszernych prac Karola Łopateckiego poświęconych temu zagadnieniu: jednej na temat prawnych aspektów dyscypliny w wojskach zaciężnych, a drugiej w pospolitym ruszeniu Obojga Narodów.

Obydwie monografie stoją na bardzo wysokim poziomie i mają szansę (obok prac Urszuli Augustyniak, Tomasza Ciesielskiego i Przemysława

ków 2008; o obowiązku służby wojskowej w średniowiecznej Brabancji: S. Boffa, Warfare in Medieval Brabant, 1356-1406, Woodbridge 2004, s. 201-224; o przymusowej służbie wojskowej na wczesnonowożytnych Łużycach: Ł. Tekiela, Wojna trzydziestoletnia na Górnych Łużycach: Aspekty militarne, Racibórz 2010, s. 46-50.

5 Th. Hippler, Citizens, Soldiers and National Armies: Military Service in France and Germany, 1789-1830, Oxon 2008, s. 101-109, 204-209.

${ }^{6}$ Podsumowanie dotychczasowego stanu debaty o rewolucji militarnej w języku polskim: J. Maroń, Wokót teorii rewolucji militarnej: Wybrane problemy, Wrocław 2011, s. 13-77.

${ }^{7}$ Ostatnio: Th. Schwager, Militärtheorie im Späthumanismus: Kulturtransfer taktischer und strategischer Theorien in den Niederlanden und Frankreich (1590-1660), Berlin 2012, s. 4-6. Za zwrócenie uwagi na tę pozycję pragnę podziękować Panu Dr. Przemysławowi Gawronowi.

${ }^{8}$ M. Foucault, Nadzorować i karać: Narodziny więzienia, przeł. T. Komendant, Warszawa 1993, s. 161-169.

${ }^{9}$ Szczegółowo literaturę przedmiotu omówił K. Łopatecki (,Disciplina militaris”, s. 16-21 i Organizacja, prawo i dyscyplina, s. 16-20). 
Gawrona $^{10}$ ) trafić do grona najważniejszych opracowań dotyczących szeroko pojętej wojskowości staropolskiej, które wydano w ostatnich latach. Również na polu historii systemu prawnego I Rzeczypospolitej trudno znaleźć w ostatnich czasach studia, które by tak kompleksowo przedstawiały jakąś gałąź prawa w dłuższej perspektywie chronologicznej (takim przykładem może być ostatnie studium Mariana Mikołajczyka ${ }^{11}$ ). Łopatecki pomimo wyznaczenia dla swoich badań ambitnych ram czasowych i przestrzennych (Korona i Litwa od końca XV do połowy XVII stulecia), a w praktyce także rzeczowych ( $\mathrm{tj}$. wojska zaciężne i pospolite ruszenie - gdyż obie prace należy traktować jako swego rodzaju całość) wyczerpująco naświetlił normatywne aspekty dyscypliny wojskowej $\mathrm{i}$ - przede wszystkim - historię źródeł prawa wojskowego obowiązującego w ówczesnej Rzeczypospolitej. Wystarczy wskazać, że białostocki badacz rozwikłał niemal wszystkie zagadki związane z okolicznościami powstania najważniejszych aktów normatywnych dotyczących dyscypliny wojskowej (na szczególną uwagę zasługują passusy poświęcone prawotwórczej działalności hetmanów wielkich koronnych: Jana Tarnowskiego i Jana Zamoyskiego, a także genezie sejmowej aprobaty dla artykułów wojskowych w 1609 r. $^{12}$ ), a w wielu przypadkach całkowicie zrewidował dotychczasowe błędne ustalenia (zwłaszcza w przypadku tzw. Ordynacji sądów wojskowych, którą w dotychczasowej literaturze niesłusznie przypisywano Janowi Kazimierzowi, i artykułów wojskowych pospolitego ruszenia z $1537 \mathrm{r}^{13}$ ). Co prawda, z niektórymi twierdzeniami autora można polemizować (np. kwestia domniemanej reasumpcji artykułów wojskowych Hrehorego Chodkiewicza w $1611 \mathrm{r}^{14}$ ), ale wyniki omawianych badań bez wątpienia staną się podstawą wszelkich dalszych dociekań na temat dyscypliny wojsk Rzeczypospolitej w XVI i w pierwszej połowie XVII w.

Osiągnięcia autora są efektem szeroko zakrojonej, wnikliwej kwerendy archiwalnej i bibliotecznej przeprowadzonej w instytucjach krajowych i zagranicznych. Badaczowi udało się poszerzyć zasób znanych dotychczas zabytków prawa wojskowego. Na podkreślenie zasługuje przede wszystkim dogłębne wykorzystanie materiałów z kolekcji tzw. Autografów Dubrowskie-

${ }^{10}$ U. Augustyniak, $W$ stużbie hetmana i Rzeczypospolitej: Klientela wojskowa Krzysztofa Radziwitla (1585-1640), Warszawa 2004; T. Ciesielski, Armia koronna w czasach Augusta III, Warszawa 2009; P. Gawron, Hetman koronny w systemie ustrojowym Rzeczypospolitej w latach 1581-1646, Warszawa 2010.

${ }^{11}$ M. Mikołajczyk, Proces kryminalny w miastach Małopolski XVI-XVIII wieku, Katowice 2013.

${ }^{12}$ K. Łopatecki, „Disciplina militaris”..., s. 137-163, 249-268, 617-637.

${ }^{13}$ Ibidem, s. 528; idem, Organizacja, prawo i dyscyplina ..., s. 106-111, 571-572.

${ }^{14}$ Idem, ,Disciplina militaris”..., s. 395-401. Naszym zdaniem nie ma wystarczających dowodów, by odrzucić twierdzenie S. Kutrzeby o pomyłce kopisty. Jest to hipoteza najprostsza i nie wymagająca dodatkowych i wątpliwych założeń. 
go (w zbiorach Rosyjskiej Biblioteki Narodowej w Sankt-Petersburgu), które dotychczas nie zostały właściwie spożytkowane jako źródło do badania prawa wojskowego państwa polsko-litewskiego, a także wprowadzenie do obiegu naukowego księgi pospolitego ruszenia ziemi liwskiej (w zbiorach Lwowskiej Naukowej Biblioteki Narodowej Akademii Nauk Ukrainy im. Wasyla Stefanyka, została ona pomyłkowo przypisana przez autora ziemi wiskiej ${ }^{15}$ ). Warto dodać, że potwierdza to zauważaną od pewnego czasu tendencję, iż najwięcej nowych i wartościowych źródeł do dziejów Rzeczypospolitej Obojga Narodów znaleźć można w archiwach i bibliotekach znajdujących się za wschodnią granicą obecnej Rzeczypospolitej ${ }^{16}$.

Karolowi Łopateckiemu można jednak wskazać pewne drobne potknię$\operatorname{cia}^{17}$. Tomasz Zamoyski nigdy nie był głównodowodzącym wojska koronnego w czasie wojny o ujście Wisł dowodził tam jedynie pułkiem jazdy ${ }^{18}$. Robert Monro nie był kronikarzem, ale szkockim oficerem w służbie szwedzkiej, zaś jego dzieło jest zapisem wspomnień z czasów wojny trzydziestoletniej $^{19}$. Jeżeli chodzi o sposoby wyliczania żołdu żołnierzom autoramentu cudzoziemskiego ${ }^{20}$, warto może wspomnieć o stosowanym w wojsku koronnym tzw. niemieckim tygodniu (ośmiodniowym), który pozwalał szefom jednostek na potrącanie swoim podkomendnym nawet $1 / 12$ rocznego żołdu ${ }^{21}$. Również $\mathrm{w}$ innych armiach europejskich stosowano podobne zabiegi (naliczania okresów, za które należała się określona kwota żołdu) w celu zapewnienia dodatkowego dochodu oficerom albo poczynienia dodatkowych oszczędności w kasie państwowej ${ }^{22}$. Podobnie przy omawianiu stosunku Władysława IV do pojedynków ${ }^{23}$ można odnieść się do słynnego starcia regimentu gwardii pieszej pod dowództwem płk. Reinholda Rosena z królewską chorągwią husar-

${ }^{15}$ Lwowska Naukowa Biblioteka Narodowej Akademii Nauk Ukrainy im. Wasyla Stefanyka, f. 4, op. I, rkps nr 67, k. 29 i nn.; K. Łopatecki, Organizacja, prawo i dyscyplina ..., passim (począwszy od s. 10). Należy zaznaczyć, że ziemia, której dotyczy to źródło została natomiast prawidłowo określona w aneksie: K. Łopatecki, Organizacja, prawo i dyscyplina..., s. 595-598 (choć przyp. 26 nadal odnosi się do ziemi wiskiej).

${ }^{16} \mathrm{~Np}$. W. Kriegseisen, Źródla do historii Rzeczypospolitej szlacheckiej w Narodowym Archiwum Historycznym Białorusi w Mińsku, „Kwartalnik Historyczny”, R. 106/4 (1999), s. 87-105.

${ }^{17}$ Poważnym problemem pierwszej publikacji jest bardzo duża liczba literówek, zwłaszcza w cytatach obcojęzycznych, co obciąża jednak przede wszystkim korektę.

${ }^{18}$ K. Łopatecki, „Disciplina militaris”..., s. 506, jedyną całościową monografią dotyczącą działań wojennych w Prusach w latach 1626-1629 jest w dalszym ciągu A. Szelągowski, O ujście Wisty: Wielka wojna pruska, Warszawa 1905.

${ }^{19}$ K. Łopatecki, ,,Disciplina militaris”,.., s. 469; D. Stevenson, Monro, Robert (d. 1675?), [w:] Oxford Dictionary of National Biography, Oxford 2004 [dostęp cyfrowy, 27 XI 2013 r.: http://www. oxforddnb.com/view/article/18978/2004-09.

${ }^{20}$ K. Łopatecki, ,,Disciplina militaris”,.., s. 487.

${ }^{21}$ J. Wimmer, Wojsko polskie w drugiej połowie XVII wieku, Warszawa 1965, s. 294-295.

${ }^{22}$ D. Parrott, Richelieu's Army: War, Government and Society in France, 1624-1642, Cambridge (UK) 2001, s. 172-173.

${ }^{23}$ K. Łopatecki, ,,Disciplina militaris”..., s. 515. 
ską pod Borysowem w sierpniu $1633 \mathrm{r}^{24} \mathrm{~W}$ tym kontekście jeszcze trudniej zrozumieć dość liberalne przepisy Listu artykułów żołnierskich, gdyż monarcha zakazał oficerom swojego regimentu pieszego odpowiadać na wyzwania towarzyszy autoramentu narodowego.

Wątpliwości może budzić również określenie żołnierzy cudzoziemskich zaciągniętych na służbę koronną w 1612 r. mianem landsknechtów. Co prawda część historyków uważa, że termin ten można stosować nawet do oddziałów istniejących w czasie wojny trzydziestoletniej ${ }^{25}$, jednakże za właściwszą uznaję definicję wiążącą to pojęcie z konkretnym typem oddziałów rekrutowanych na terenie Rzeszy w XVI w., odznaczających się charakterystyczną organizacją, dużym stopniem samorządności i właśnie specyficznym podejściem do dyscypliny wojskowej ${ }^{26}$ (stąd nie jest to wyłącznie kwestia terminologiczna). 400-konną jednostkę rajtarii Mikołaja Abrahamowicza należałoby raczej określić mianem regimentu, a nie kompanii ${ }^{27}$. Bylibyśmy także ostrożni w podkreślaniu dużego wpływu doświadczeń z zagranicznych peregrynacji (zwłaszcza do Niderlandów) na kształt reform dyscyplinarnych w wojsku koronnym i litewskim ${ }^{28}$. Jak wykazuje bowiem David Parrott na przykładzie armii francuskiej - wpływ rozwiązań północnoniderlandzkich na organizację i taktykę wojsk Burbonów był raczej powierzchowny i ograniczał się w dużej mierze do sfery retoryki i - ogólnie - dyskursu teoretyczno-wojskowego ${ }^{29}$.

Problematyczne wydaje się sytuowanie początków prawa humanitarnego w XVI w. ${ }^{30}$ Ówczesne normy chroniące ludność cywilną można raczej wywieść ze średniowiecznych reguł o charakterze religijnym, a ich podobieństwo do współczesnego prawa genewskiego jest dość ograniczone ${ }^{31}$. To ostatnie jest

${ }^{24}$ Diariusz kampanii smoleńskiej Władysława IV, 1633-1634, oprac. M. Nagielski, Warszawa 2006, s. 79-80, 199-200.

${ }^{25}$ K. Łopatecki, ,Disciplina militaris”..., s. 471; M. Plewczyński, Daj nam, Boże, sto lat wojny: Dzieje niemieckich lancknechtów 1477-1559, Warszawa 1997, s. 6.

${ }^{26}$ O. v. Nimwegen, The Transformation of Army Organization in Early-Modern Western Europe, c. 1500-1789, [w:] European Warfare, 1350-1750, Cambridge (UK) 2001, s. 161-167.

${ }^{27}$ K. Lopatecki, ,Disciplina militaris”..., s. 505. Skądinąd wiadomo, że jednostka ta dzieliła się na trzy chorągwie. Dlatego też „regiment” jest najwłaściwszym określeniem, J. Teodorczyk, Bitwa pod Gniewem (22 IX-29 IX-1 X 1626): Pierwsza porażka husarii, „Studia i Materiały do Historii Wojskowości”, t. XII/2 (1966), s. 126.

${ }^{28}$ K. Łopatecki, ,Disciplina militaris”..., s. 507-508.

${ }^{29}$ D. Parrott, Richelieu's Army..., s. 24-38. Co ciekawe - sam Parrott dla poparcia swej tezy powołuje się na poświęcony Rzeczypospolitej artykuł R. Frosta, The Polish-Lithuanian Commonwealth and the 'Military Revolution', [w:] Poland and Europe: Historical Dimensions. Selected Essays from the 50th Anniversary International Congress of the Polish Institute of Arts and Sciences in America, ed. J.S. Pula and M.B. Biskupski, Boulder 1994, s. 19-47. Na kulturowe aspekty reform orańskich ostatnio zwraca uwagę Th. Schwager, op. cit., passim.

${ }^{30}$ K. Łopatecki, ,Disciplina militaris”..., s. 155-156; w podobnym duchu także przywoływany przez Łopateckiego K. Ögren, Humanitarian Law in the Articles of War decreed in 1621 by King Gustavus Adolphus of Sweden, „International Review of the Red Cross”, vol. 36 (1996), s. 438-442.

${ }^{31}$ M. Bennett, Legality and Legitimacy in War and Its Conduct, [in:] European Warfare, 1350-1750, ed. F. Tallett, D.J.B. Trim, Cambridge (UK) 2010, s. 267. 
oparte przede wszystkim na humanitarnych ideach oświecenia i obejmuje nie tylko kwestie związane z ochroną ludności cywilnej, lecz także jeńców i poprawę losu rannych (to właśnie ta ostatnia sprawa leży u jego genezy) ${ }^{32}$. Należy również odnotować, że w II połowie XVII stulecia nawet w świadomości najwyższych dowódców wojsk Rzeczypospolitej terytorium nieprzyjacielskie było obszarem, na którym nie obowiązywały niemal żadne regulacje dotyczące rabunku i krzywdzenia cywili. Najlepszym przykładem jest obrazowy fragment z pamiętnika towarzysza husarskiego Jana Władysława Poczobuta Odlanickiego, opisujący zachowanie hetmana polnego litewskiego Michała Kazimierza Paca przy przekraczaniu granicy moskiewskiej. Mianowicie Pac „za najściem o półtory mile w moskiewską ziemię, s a m [podkr. - J.J. S.] ogień włożył w dach jednej słobody, która na granicy była, dawszy w imię Boże licencyją palić i ścinać" 33 . Oszczędzanie terytorium nieprzyjacielskiego zdecydowanie nie leżało w logice ówczesnej wojny, a normy chroniące zamieszkującą je ludność były w dużej mierze elementem propagandowym mającym podkreślić przywiązanie wydawcy danego aktu do chrześcijańskich zasad moralnych.

Autor $\mathrm{w}$ podsumowaniu pracy ${ }^{34}$ podkreśla rolę partykularyzmu prawa wojskowego - ujmowanego jako rządzenie się innymi prawami przez różne rodzaje, czy nawet zgrupowania wojsk. Warto jednakże zwrócić uwagę na jeszcze jeden partykularyzm niejako ,wbudowany” w ówczesne prawo wojskowe, a mianowicie partykularyzm stanowy. Inne reguły (a zwłaszcza sankcje) obowiązywały osoby szlacheckiego i nieszlacheckiego pochodzenia ${ }^{35}$, co jeszcze bardziej uwidaczniało się w praktyce sądownictwa wojskowego ${ }^{36}$. Partykularyzm ten wynikał z rozpowszechnionego wówczas przekonania o naturalnej zdatności szlachty do zawodu żołnierza i jej zdecydowanie większej wiarygodności ${ }^{37}$. Należy też dodać, że kara wieży - wedle autora: „,bardzo rzadko stosowana w prawie wojskowym" 38 na przełomie XVI i XVII w. - była relatywnie często stosowana przez sąd hetmański sto lat później ${ }^{39}$. Być może jest to efektem upodobniania się prawa wojskowego do prawa ziemskiego w ciągu XVII stulecia.

${ }^{32}$ The Handbook of Humanitarian Law in Armed Conflicts, ed. D. Fleck, Oxford 1995, s. 112, 116.

33 J.W. Poczobut Odlanicki, Pamiętnik [1640-1684], oprac. A. Rachuba, Warszawa 1987, s. 188 (zdarzenie miało miejsce 14 stycznia 1664 r.).

${ }^{34}$ K. Łopatecki, ,Disciplina militaris”..., s. 695-697.

${ }^{35} \mathrm{~Np}$. ibidem, s. 375.

${ }^{36}$ J.J. Sowa, ,W czym vertitur powaga moja hetmańska... ”: Organizacja i procedura sadu hetmańskiego w Koronie w latach 1683-1699, „Czasopismo Prawno-Historyczne”, t. LXV/1 (2013), s. 222.

${ }^{37}$ Por. opinia hetmana Jana Tarnowskiego, K. Łopatecki, ,, Disciplina militaris”..., s. 62, także fragment poświęcony piechocie szlacheckiej: s. 495-502.

${ }^{38}$ K. Łopatecki, ,,Disciplina militaris”..., s. 316.

39 J.J. Sowa, „W czym vertitur...”, s. 222-223. 
Jeżeli chodzi o wykorzystaną literaturę, to porównawcze aspekty omawianych monografii - głównie w podrozdziale Angielskie prawo wojenne w systemie prawnym - analiza porównawcza - wzbogaciłyby prace: Fernanda Gonzáleza de León poświęcona przede wszystkim korpusowi oficerskiemu Armii Flandrii, ale zawierająca wiele informacji na temat wymiaru sprawiedliwości, dyscypliny, a także relacji z ludnością cywilną w wojskach hiszpańskich na przełomie XVI i XVII w. ${ }^{40}$, oraz Johna Childsa poświęcona armii angielskiej i szkockiej w II połowie XVII w., w której znajduje się próba wyjaśnienia złożonych relacji pomiędzy military law i martial law a common law w Wielkiej Brytanii doby restauracji i Wilhelma III ${ }^{41}$.

Istotniejszą kwestią są tytuły obydwu prac. Sformułowania „,Disciplina militaris" w wojskach Rzeczypospolitej oraz Organizacja, prawo i dyscyplina $w(. .$.$) pospolitym ruszeniu mogą sugerować, że obie pozycje kompleksowo$ opisują wszystkie zagadnienia związane z dyscypliną wojskową w Koronie i na Litwie XVI i początku XVII w. Autor we wstępach obydwu prac lojalnie uprzedza, co jest właściwym przedmiotem jego studiów. Pierwsza monografia jest zatem historią źródeł prawa wojskowego obowiązujących w wojskach zaciężnych, a druga - obok podobnego przedstawienia genezy i treści aktów normatywnych dotyczących pospolitego ruszenia - dodatkowo prezentuje prawno-instytucjonalne aspekty organizacji i służby tego rodzaju sił zbrojnych. Niemniej jest to bardzo istotny, ale - co zresztą autor zauważa - jednak wycinek całości zagadnień związanych z dyscypliną wojskową we wczesnonowożytnej Rzeczypospolitej. Dla uzyskania pełnego obrazu potrzeba przede wszystkim zbadania: sądownictwa wojskowego (zarówno w aspekcie normatywnym, jak i praktycznym), pozasądowych i pozaprawnych (np. za pomocą relacji natury klientalnej) sposobów utrzymywania dyscypliny, faktycznych rozmiarów przestępczości wojskowej (w relacjach wewnątrzarmijnych i wobec ludności cywilnej), wpływu na dyscyplinę systemów wynagradzania i zaopatrzenia żołnierzy ${ }^{42}$ oraz elementów mentalności żołnierskiej związanej z dyscypliną i posłuszeństwem.

Oczywiście jest to program badawczy niemożliwy do zrealizowania przez pojedynczego historyka w szerszych ramach chronologicznych, ale warto by podjąć próbę takiego całościowego przedstawienia dyscypliny wojskowej w krótszym okresie czasu (np. jednego konfliktu zbrojnego czy panowania jednego władcy). Ponadto, choć część zagadnień stała się już przedmiotem

${ }^{40}$ F. González de León, The Road to Rocroi: Class, Culture, and Command in the Spanish Army of Flanders, 1597-1659, Boston-Leiden 2009.

41 J. Childs, The Army of Charles II, London 1976; idem, The British Army of William III, 1689-1702, Manchester 1987.

42 Przykładem takiej analizy może być podrozdział poświęcony związkom rozliczeń finansowych pomiędzy państwem i oficerami a wydawaniem artykułów rotmistrzowskich: K. Łopatecki, ,Disciplina militaris”..., s. 65-70. 
opracowań, istnieją jeszcze spore luki. Najsłabiej zbadane jest sądownictwo wojskowe ${ }^{43}$ i mentalność żołnierska ${ }^{44}$.

Złożoność obszaru badawczego pozostaje w ścisłym związku z charakterem samego przedmiotu. Dyscyplina w europejskich siłach zbrojnych epoki wczesnonowożytnej do XVIII w. miała charakter „płynny”. Dobrym odniesieniem jest metafora zastosowana przez D. Parrotta przy wyjaśnianiu niemożności określenia dokładnego stanu liczebnego armii wczesnonowożytnych ${ }^{45}$. Porównał on armię francuską z I połowy XVII w. do wanny bez zatkniętego korka, do której dolewa się co jakiś czas wody - rekrutuje nowych żołnierzy, jako że wody jednak cały czas ubywa - armia ponosi straty zarówno bojowe, jak i przede wszystkim niebojowe, nie można dokładnie ocenić jej stanu liczebnego. Podobnie jest naszym zdaniem z dyscypliną wojskową. Nie była ona bowiem ustalana za pomocą konkretnego aktu normatywnego raz na zawsze, ale wymagała stałego utwierdzania (owego parrottowskiego „dopływu wody”) wielokrotnym wydawaniem kolejnych takich aktów, uniwersałów, ordynansów do wojska, działaniami wojskowego wymiaru sprawiedliwości, pokazowymi egzekucjami, urządzaniem popisów, nabożeństw, instrumentami związanymi z relacjami natury klientalnej itp. ${ }^{46}$ Było to związane $\mathrm{z}$ dużą fluktuacją składu osobowego ówczesnych armii ${ }^{47}$, ale też $\mathrm{z}$ tym, że dopiero w XVIII stuleciu wykształcone zostały w społeczeństwach europejskich odpowiednie nawyki dyscyplinarne, które sprawiły, że trafiający do wojska rekruci łatwiej ulegali panującemu tam rygorowi ${ }^{48}$. Stąd też przed tym okresem dyscyplina była przede wszystkim ową trudno uchwytną „duszą armii” realizującą się nie tylko poprzez akty prawne, ale także faktyczne działania dowódców, a droga od przepisu do

${ }^{43} \mathrm{Na}$ ten temat: J.J. Sowa, ,W $W$ czym vertitur ..., s. 203-204.

${ }^{44}$ Poza dotyczącą ogólniejszych zagadnień i specyficznej grupy pracą J. Ronikiera, Hetman Adam Sieniawski i jego regimentarze: Studium z historii mentalności szlachty polskiej 1706-1725, Kraków 1992, istnieje w zasadzie tylko rozdział w opracowaniu U. Augustyniak, op. cit., s. 123-170 i artykuł A. Czekaj, Obywatele czy kondotierzy?: Postawy obywatelskie i moralne żotnierzy narodowego autoramentu wojsk Rzeczypospolitej w pierwszej połowie XVII w., [w:] Staropolska sztuka wojenna XVI-XVII wieku: Prace ofiarowane profesorowi Jaremie Maciszewskiemu, red. M. Nagielski, Warszawa 2002, s. 85-101.

${ }^{45}$ D. Parrott, Richelieu's Army..., s. 178-179.

${ }^{46}$ Dobry przykład różnorodnych działań dowódcy mających na celu utrzymanie dyscypliny zawiera tzw. diariusz kancelaryjny Janusza Radziwiłła z lat 1648-1652: Archiwum Główne Akt Dawnych w Warszawie, Archiwum Radziwiłłów, dz. VI, pudło 36 i 37/1, passim.

${ }^{47}$ Według badań M. Wagnera zdecydowaną większość kadry oficerskiej wojska koronnego z II połowy XVII w. można określić mianem niezawodowej: M. Wagner, Kadra oficerska armii koronnej w drugiej połowie XVII wieku, Toruń 1995, s. 188.

${ }^{48}$ Najdoskonalszym przykładem takiej militaryzacji społeczeństwa jest oczywiście pruski system kantonalny: Th. Hippler, op. cit., s. 121-131. O habsburskiej militaryzacji i jej instrumentach: M. Hochedlinger, The Habsburg Monarchy: From 'Military Fiscal State' to 'Militarization', [w:] The Fiscal-Military State in Eighteenth-Century Europe: Essays in Honour of P.G.M. Dickson, ed. Ch. Storrs, Farnham 2009, s. 85-94. 
jego egzekucji była dużo dłuższa i bardziej skomplikowana niż w armiach XIX i XX w.

W związku z tym warto zastanowić się: czy, w ogólnej perspektywie, autor nie przypisuje zbyt dużego znaczenia literalnemu brzmieniu poszczególnych przepisów, wymiarów sankcji i podobnym czynnikom ${ }^{49}$. Praktyka (przynajmniej z końca XVII w.) pokazywała, że sądy wojskowe do litery artykułów hetmańskich podchodziły dość swobodnie ${ }^{50}$. Trzeba też pamiętać, że artykuły wojskowe pełniły w dużej mierze funkcję propagandową, przeznaczoną dla cywilnego, szlacheckiego odbiorcy. Na to przecież skarżył się - przywoływany przez autora - Jakub Zawisza ${ }^{51}$. Aby więc wskazywać na rzeczywiste znaczenie konkretnych zmian, np. sankcji za dane przestępstwo, trzeba najpierw zbadać praktykę sądową dotyczącą karania owego przestępstwa, jak też i jego miejsce w ówczesnym dyskursie prawnym i wojskowym $^{52}$. Wreszcie powinno się mieć wzgląd na odmienność ówczesnej techniki prawodawczej ${ }^{53}$.

Koncepcja „płynnej” dyscypliny nasuwa ważne pytanie, postawione zresztą przez autora ${ }^{54}$, a mianowicie: dlaczego w Koronie (w przeciwieństwie do Wielkiego Księstwa Litewskiego) po 1609 r. doszło do znacznego ograniczenia praktyki dalszego wydawania artykułów hetmańskich przed poszczególnymi kampaniami. Zagadnienie to wymaga szerszych badań, pewnym wyjaśnieniem może być jednak silniejsza pozycja hetmana wielkiego koronnego od jego litewskiego odpowiednika ${ }^{55}$. Warto zwrócić uwagę na formuły dekretów hetmańskich z końca XVII w., które w artykułach wojskowych i prawie pospolitym widziały raczej samo źródło władzy hetmańskiej niż konkretne zalecenia dla hetmana związane z wymiarem sprawiedliwości, czy innymi działaniami dyscyplinującymi ${ }^{56}$. Hetman koronny, dysponujący bardzo rozległymi kompetencjami (także, a może - zwłaszcza w dziedzinie finansowej),

${ }^{49}$ Najlepsze przykłady takiej szczegółowej analizy: K. Łopatecki, „Disciplina militaris”..., s. $256-259,513-520$.

${ }^{50}$ J.J. Sowa, ,W czym vertitur ..., s. 221-222.

${ }^{51}$ K. Łopatecki, ,Disciplina militaris”..., s. 648.

52 Kwestie związane z niektórymi przestępstwami wojskowymi były bardzo mocno obecne $\mathrm{w}$ ówczesnej publicystyce, np. problem nadużyć przy wybieraniu stacji regularnie pojawia się w twórczości Szymona Starowolskiego (Rozmowa żotnierza z plebanem o stacja, Kraków 1624; Stacje żotnierskie, Kraków 1636; Prawy rycerz, Kraków 1648; Zguba ojczyzny stacje, Kraków b.d. [po 15 sierpnia 1649 r.]).

${ }^{53}$ Co zauważa we wstępie sam K. Łopatecki, „Disciplina militaris”..., s. 23, przyp. 70.

${ }^{54}$ K. Łopatecki, ,Disciplina militaris”..., s. 644.

${ }^{55}$ P. Gawron, Hetman koronny..., s. 459-462; A. Czwołek, Konflikty i spory wśród dowódców litewskich $w$ czasie wojny $w$ Inflantach $w$ latach 1625-1629 $i$ ich wplyw na przebieg działan militarnych, [w:] Wojny pótnocne w XVI-XVIII wieku: W czterechsetlecie bitwy pod Kircholmem, red. B. Dybaś, Toruń 2007, s. 93-104.

${ }^{56}$ Biblioteka XX. Czartoryskich w Krakowie (dalej: BCzart.), rkps 2679 i 2699, passim, Biblioteka Zakładu Narodowego im. Ossolińskich we Wrocławiu, rkps nr 250, passim. 
mógł łatwo odwoływać się do innych środków dyscyplinowania żołnierzy, a nie tylko wydawania kolejnych artykułów wojskowych.

Wprowadzenie surowszych regulacji dyscyplinarnych uniemożliwiał również wzrost roli politycznej samego wojska koronnego. Już konfederacja żołnierska z 1622 r. domagała się złagodzenia sankcji prawa wojskowego ${ }^{57}$. Kolejne konfederacje wyniosły wojsko niemal do roli czwartego stanu sejmującego, stąd każda próba wprowadzenia nowego prawa wbrew wojskowym mogła prowadzić do wypowiedzenia posłuszeństwa przez armię $e^{58}$.

Pewien niedosyt może budzić ostatni podrozdział zakończenia pracy o dyscyplinie wojskowej dotyczący rewolucji militarnej59. Wydaje się bowiem, że zagadnienie to można by rozwinąć. Warto zauważyć, że przemiany form dyscyplinowania żołnierzy (choć oczywiście dużo mniej radykalne) zarówno w wojskach zaciężnych, jak i pospolitym ruszeniu na Litwie i w Koronie zachodziły niemal równolegle do podobnych przemian na zachodzie Europy $^{60}$. Można nawet - toutes proportions gardées - porównać wojny inflanckie z wojną osiemdziesięcioletnią w Niderlandach. W obydwu przypadkach były to długotrwałe wojny na relatywnie dobrze ufortyfikowanym terytorium i w obydwu przypadkach wymuszały one głębokie reformy militarne i finansowe na walczących stronach ${ }^{61}$. Działania wojenne w Inflantach i na pograniczu moskiewskim miały charakter pozycyjny w takim sensie, że wojsko kwaterowało przez dłuższy czas w tych samych miejscach, a duże znaczenie miały operacje związane ze zdobywaniem i utrzymywaniem punktów umocnionych (oblężenia, blokady, wypady załóg, osłona własnej bazy zaopatrzeniowej przed wypadami nieprzyjaciela). Innymi słowy: istniała konieczność stworzenia całego systemu ochrony pogranicza. Była to sprzyjająca okoliczność dla wydawania różnych aktów normatywnych, mających - w swoim

57 J. Pietrzak, Konfederacja lwowska w 1622 roku, „Kwartalnik Historyczny”, t. LXXX/4 (1973), s. 849.

${ }^{58} \mathrm{Na}$ temat stosunku żołnierzy do niektórych aspektów prawa wojskowego w I połowie XVII w.: P. Gawron, Żolnierz i trybunaty w siedemnastowiecznej koronie: Na marginesie artykulu Karola Łopateckiego „Egzempcje wojskowe - immunitet żolnierski w Rzeczypospolitej Szlacheckiej XVI-XVII wieku”, ,Zeszyty Prawnicze [UKSW]”, 5.1 (2005), s. 101-145, „Zeszyty Prawnicze [UKSW]", t. 7.1 (2007), s. 293-310.

${ }^{59}$ K. Łopatecki, ,Disciplina militaris”..., s. 701-702.

${ }^{60} \mathrm{~Np}$. ibidem, s. 287-294 i 310-315.

${ }^{61} \mathrm{Na}$ temat charakteru wojny osiemdziesięcioletniej i jej wpływu na europejską wojskowość przede wszystkim klasyczna praca G. Parkera, The Army of Flanders and the Spanish Road, 1567-1659, Cambridge (UK) 2004, zwłaszcza s. 1-2; z nowszych ujęć: F. González de León, op. cit., passim i Th. Schwager, op. cit., passim. Znaczeniem jednego z etapów wojny inflanckiej dla Wielkiego Księstwa Litewskiego zajął się A. Ânuškevič, Ливонская война 1558-1570 г2. и Великое княжество Литовское, Minsk 2013 (praca ta oparta jest jednak na niekompletnej bazie źródłowej i w zasadzie pozbawiona porównań z podobnymi procesami w innych państwach), zaś na tematy finansowe ostatnio: A. Tyla, Lietuvos Didžiosios Kunigaikštystès iždas: XVI amziaus antroji pusé - XVII amžiaus vidurys, Vilnius 2012. Problematyka ta wciąż wymaga dalszych badań - zwłaszcza - w kontekście ogólnoeuropejskim. 
zamierzeniu - na dłużej stworzyć prawne podstawy funkcjonowania tego systemu. Jako przykłady z drugiej połowy XVII w. można przywołać francuski system obrony północnej granicy ${ }^{62}$, a na gruncie polsko-litewskim - obronę południowo-wschodniego pogranicza w czasie wielkiej wojny tureckiej. Wydane wówczas konstytucje sejmowe (zwłaszcza konstytucje: Konsystencyje wojska koronnego z 1685 r., Indemnitas dóbr dziedzicznych i Lokacyja wojska z 1690 r., a przede wszystkim scriptum ad archivum z tegoż sejmu ${ }^{63}$ ) i regulacje dyscyplinarne hetmana wielkiego koronnego Stanisława Jabłonowskiego zawarte $\mathrm{w}$ rozlicznych ordynansach i uniwersałach ${ }^{64}$ były niewątpliwie związane z przyjętą wówczas koncepcją osłony Rusi i Wołynia przed najazdami tatarskim. Duże znaczenie odgrywała także kwestia utrzymania punktów umocnionych (na czele z nowo powstałymi Okopami św. Trójcy i Szańcem Panny Marii, a także forteczkami mołdawskimi), stąd problem dyscypliny stacjonujących tam oddziałów szczególnie zaprzątał uwagę głównodowodzącego $^{65}$ - analogicznie jak w XVI-wiecznych zamkach inflanckich.

Przemiany w zakresie dyscypliny i organizacji sił zbrojnych widać również na przykładzie pospolitego ruszenia, które starało upodobnić się do wojsk zaciężnych $^{66}$.

Z drugiej strony, nie sposób nie zauważyć, że na pewnym etapie rewolucja militarna w polsko-litewskiej Rzeczypospolitej zatrzymała się. Pomocna w wyjaśnieniu tego zjawiska może być koncepcja Olafa van Nimwegena, który wskazuje na trzy etapy przemian sił zbrojnych we wczesnonowożytnej Europie:

- okres ,wolnego żołnierza” (landsknechtów),

- okres zdyscyplinowanego „najemnika"67,

- okres stałej armii zawodowych żołnierzy ${ }^{68}$.

Można zaryzykować twierdzenie, że działania władz państwowych i oficerów były hamowane przez szlachecką mentalność autoramentu narodowe-

${ }^{62} \mathrm{Na}$ temat jego funkcjonowania w czasie wojny holenderskiej G. Satterfield, Princes, Posts and Partisans: The Army of Louis XIV and Partisan Warfare in the Netherlands (1673-1678), Leiden-Boston 2003, s. 215-217, 225-250.

${ }^{63}$ Volumina legum, wyd. J. Ohryzko, t. V, Sankt-Petersburg 1860, s. 346-347, 372-373; scriptum ad archivum z 1690 r.: BCzart., rkps nr 183, s. 297-300.

${ }^{64}$ BCzart., rkps 2679 i 2699, passim; M. Wagner, Prawa i obowiazki oficerów armii koronnej $w$ drugiej połowie XVII w.: Ze studiów nad rozwojem prawa wojskowego w dawnej Rzeczypospoli$t e j$, ,Studia i Materiały do Historii Wojskowości”, t. XXXVI (1994), s. 40-44.

${ }^{65} \mathrm{O}$ garnizonie Okopów św. Trójcy m.in. J.J. Sowa, ,Ludzie niezwalczeni”: Rejestry choragwi jazdy autoramentu narodowego w Okopach św. Trójcy 1693-1695, [w:] Studia nad staropolska sztukq wojenna, t. II, red. Z. Hundert, Oświęcim 2013, s. 259-260; ordynans dla gen.-mjr. Ottona Ernsta Rappego mianujący go komendantem Soroki, BCzart., rkps nr 2699, k. 4v-5.

${ }^{66}$ K. Łopatecki, Organizacja, prawo..., s. 479-541.

${ }^{67}$ Termin „najemnik” należy u Nimwegena rozumieć szeroko - jako każdego żołnierza służącego za pieniężne wynagrodzenie.

${ }^{68}$ O. van Nimwegen, op. cit., s. 162-171. 
go - najważniejszej i najaktywniejszej politycznie części wojska. Podczas gdy zamiarem czynników decyzyjnych byłoby stworzenie zdyscyplinowanego, stałego wojska zaciężnego, podporządkowanego hetmanowi, królowi i sejmowi, to sami żołnierze chcieli zachować daleko posuniętą autonomię niejako zatrzymać się w okresie „wolnego żołnierza”. Jeszcze w 1696 r. konfederaci żołnierscy będą wysuwali postulat wyboru poruczników przez ogół towarzyszy danej chorągwi ${ }^{69}$. Wyrazem samorządu żołnierskiego jest także funkcjonowanie kół wojskowych ${ }^{70}$. Dlatego też badanie żołnierskiej tożsamości i mentalności może $\mathrm{w}$ dużym stopniu rozjaśnić kwestię porażki modernizacji wojskowej w państwie polsko-litewskim.

Niepełny charakter transformacji sił zbrojnych Rzeczypospolitej dobrze widać również na przykładzie sądownictwa wojskowego. Autor wspomina o trzech modelach sądownictwa wojskowego w ówczesnej Europie ${ }^{71}$. Można tu dodać model czwarty: władza sądownicza nad wojskiem spoczywająca w rękach cywilnych, królewskich urzędników ${ }^{72}$. W Rzeczypospolitej też podejmowano próby ograniczenia władzy sądowniczej hetmanów, niemniej jednak nigdy nie zakończyły się one sukcesem. Podobnie rzecz miała się z uprawnieniami finansowymi hetmanów, które zostały im w znacznym stopniu odebrane dopiero w 1717 r. Kusi to do postawienia hipotezy, że zbyt obszerna władza hetmańska była, obok mentalności szlacheckich żołnierzy, kolejną przeszkodą w polsko-litewskiej rewolucji militarnej.

Celem niniejszego szkicu było wskazanie na możliwości rozwinięcia badań nad dyscypliną wojskową w I Rzeczypospolitej podjętych przez Karola Łopateckiego. Prace białostockiego historyka stanowią - jak widać - nie tylko źródło inspiracji, ale także znakomity punkt wyjścia i wielką pomoc przy opracowywaniu kolejnych zagadnień dotyczących przemian wojskowości dawnej Rzeczypospolitej.

${ }^{69}$ A.Ch. Załuski, Epistolae historico-familiares, t. II, Brunsberga 1711, s. 96.

${ }^{70}$ Por. J. Urwanowicz, ,, Wojskowe sejmiki”: Koła w wojsku Rzeczypospolitej XVI-XVII wieku, Białystok 1996.

${ }^{71}$ K. Łopatecki, ,Disciplina militaris”..., s. 644.

${ }^{72}$ Np. F. González de León, op. cit., s. 115-119. 